\title{
Organic and Inorganic Fertilizers Induced Yield \\ Increment of Two Pearl Millet Varieties in Sudanian and Sahelian Agro-ecological Zones in Mali
}

Halimatou Aboubacar Toure

Institut des Sciences des Sociétés (INSS), Burkina Faso

Kalifa Traore

Rural Economic Institute, Soil-Water-Plant Laboratory, Sotuba. Bamako, Mali

Idriss Serme (Corresponding author)

Institut de l'Environnement et de Recherches Agricoles (INERA),

O4 BP 8645 Ouagadougou. E-mail: sermeidriss@yahoo.fr

Korodjouma Ouattara

Institut de l'Environnement et de Recherches Agricoles (INERA),

O4 BP 8645 Ouagadougou.

Received: August 14, 2018

doi:10.5296/jas.v6i3.13646
Accepted: August 24, 2018

URL: https://doi.org/10.5296/jas.v6i3.13646

\begin{abstract}
Soil fertility is inherently low in sub Saharan Africa. The objective of this study was therefore to determine millet yield for two varieties in each zone using organic and inorganic fertiliser in two agro-ecological zones in Mali. A two-year experiment was conducted at Agricultural Research Station of Sotuba and Cinzana in 2013 and 2014. A combination of two pearl millet varieties and four fertilizer treatments were used. The fertilizers treatments used were: T1 Control (no application); T2 MANURE of 23:10:17 (5000 kg/ha); T3 NPK of 15: 15: 15 (50 $\mathrm{kg} / \mathrm{ha}$ ) and T4 combination of NPK + MANURE. The experiments were conducted in a randomised complete block design (RCBD) with four replications in a plot size of $10 \mathrm{~m} \times 4.2$
\end{abstract}


m. The varieties evaluated at Sotuba station were Sanioni, an improved local variety and Cho, a local variety while at Cinzana station Sosat, an improved variety form IER /ICRISAT and IBV8001, and an improved variety from ICRISAT were used. At Sotuba high grain with NPK+MANURE (1948 kg ha $\left.{ }^{-1}\right)$ followed by NPK (1281 kg ha'), MANURE (1130 kg ha-1) and the Control $\left(813 \mathrm{~kg} \mathrm{ha}^{-1}\right)$. In 2014, the grain yield NPK+MANURE) was $1602 \mathrm{~kg} \mathrm{ha}^{-1}$, followed by NPK (1502 kg ha $\left.{ }^{-1}\right)$, MANURE (1466 kg ha $\left.{ }^{-1}\right)$ and the control (1440 kg ha-1). The grain yield gap for the Control treatment in 2013 (813 kg ha-1) and in 2014 (1440 $\mathrm{kg} \mathrm{ha}^{1}$ ) was high compared to the NPK+MANURE, MANURE and NPK treatment grain yield gap for the same years. In Cinzana In 2013, higher grain yield with the treatments of NPK+MANURE, $\left(1440 \mathrm{kgha}^{-1}\right)>$ NPK $\left(1429 \mathrm{~kg} \mathrm{ha}^{-1}\right)>$ MANURE $\left(1416 \mathrm{~kg} \mathrm{ha}^{-1}\right)>$ Control $\left(1276 \mathrm{~kg} \mathrm{ha}^{-1}\right)$ were observed. In 2014, the highest grain yield with NPK+MANURE (1915 $\left.\mathrm{kg} \mathrm{ha}^{-1}\right)$ followed by NPK (1561 kg ha $\left.{ }^{-1}\right)$, MANURE $\left(1523 \mathrm{~kg} \mathrm{ha}^{-1}{ }^{1}\right)$ and Control $(1121 \mathrm{~kg}$ $\left.\mathrm{ha}^{-1}\right)$. The grain yield gap for the combined NPK+MANURE treatment in 2103 (1440 kg ha-1) and in 2014 (1915 $\mathrm{kg} \mathrm{ha}^{1}$ ) was high compared to the others for the fertilizer grain yield gap for both years.

Keywords: Pearl millet, Treatment, Yield, Climate variability

\section{Introduction}

In the Sudano-Sahelian zone of West Africa (SSWA) agriculture remains the main source of employment ( $80 \%$ of the population) and contribute significantly to gross domestic product (GDP) $(30 \%)$ for countries (FAO, 2012). Smallholder agricultural production is dominated by rain-fed production of millet, sorghum, maize for food consumption and cotton for the market. Farmers experience low yields resulting in increasing uncertainty about being able to produce the food needed for their families (Breman and Sissoko, 1998; Drechsel et al., 2001). Major factors contributing to low productivity are climate variability, poor soil fertility, poor agricultural management. soil fertility is inherently low (Bationo and Buerkert, 2001; Vanlauwe et al., 2010; Giller et al., 2011) and represents the main constraint for agricultural development. This situation is heightened by the reduction of cultivation of fragile lands, reduction in fallow lengths, limited use of inorganic fertilizers due to high world market fertilizer prices and limited access to credit (De Graaff et al., 2011; Ehui and Pender, 2005).

Pearl millet Pennisetum glaucum (L.) R. Br. is usually a short-day plant, while some varieties are day length neutral. Generally, it is sensitive to low temperatures at the seedling stage and at flowering. It germinates well at soil temperatures of 23 to $30{ }^{\circ} \mathrm{C}$ and high day time temperatures are important for the grain to mature. It can grow in areas receiving $200-1500$ $\mathrm{mm}$ of rainfall. Despite its drought tolerance, pearl millet requires evenly distributed rainfall during the growing season (Oushy, 2010) and drought stress during flowering through to grain fill results in low and unstable yields according to Wilson (2011). Yadav (2010) also shown out that post flowering drought stress is one of the most important environmental factors reducing pearl millet grain yield as much as $50 \%$. Too much rainfall at flowering can also cause crop failure (Oushy, 2010).

Pearl millet contributes to both rural food security and livelihood systems, as it provides good nutritional supplies and income sources to small-scale farmers (Rai et al., 2012). Pearl millet 
is an essential crop in farming systems of drought tolerant and dual-purpose crop of rainfed area. In Mali the most common cereal is millet and are remain the most widely consumed cereals, especially in rural areas and among low-income with a production of 1,157,810 $\mathrm{t}$ and a production area of about 1,484,190 ha (2005/2006) (Giller et al., 2011). It is grown in all agricultural areas of Mali mainly in Sahelian, Sudanian and northern Guinean zones with planting areas estimated respectively at 38.6\%, $21.1 \%$ and $12 \%$ (Giller et al., 2011; Traoré et al., 2000) of the total cultivated area. The choice of crop to maturity is influenced by the onset of rain and agricultural calendar of the farmer. In case of early onset of the rainy season, the relatively long cycle varieties are sown first. In case of late onset of the rainy season, the emphasis is shifted to early maturing varieties. Some of the constraints to millet production include; low yield of available cultivars, inappropriate cycle of the varieties in the erratic climatic conditions, downy mildew, water stress, low soil fertility, etc (Doumbia et al., 2008; Chakraborty and Newton, 2011).

The response of different millet varieties to both organic and inorganic fertilizer across agro ecological zones have not been well documented in Mali.

The objective of this study was to determine millet yield for two varieties in each zone using organic and inorganic fertiliser in two agro-ecological zones in Mali

\section{Materials and MethoDS}

\section{Experimental Design and Crop Management}

The computed data were obtained from two experiments conducted at Agricultural Research Station of Sotuba and Cinzana in 2013 and 2014. A combination of two pearl millet varieties and four fertilizer treatments were used. The fertilizers treatments used were: T1 Control (no application); T2 MANURE of 23:10:17 (5000 kg/ha); T3 NPK of 15: 15: 15 (50 kg/ha) and T4 combination of NPK + MANURE The experiments were conducted in a randomised complete block design (RCBD) with four replications in a plot size of $10 \mathrm{~m}$ x $4.2 \mathrm{~m}$. The varieties evaluated at Sotuba station were Sanioni, an improved local variety and Cho, a local variety while at Cinzana station Sosat, an improved variety form IER /ICRISAT and IBV8001, and an improved variety from ICRISAT were used.

The land was ploughed, harrowed and ridged in the two locations. The experiments were established at Sotuba on $15^{\text {th }}$ July, 2013 and $11^{\text {th }}$ June, 2014 and at Cinzana on the $22^{\text {th }}$ July, 2013 and $15^{\text {th }}$ July, 2014. The plants were sown on 6 rows $5 \mathrm{~m}$ long, $0.80 \mathrm{~m}$ between rows and $0.50 \mathrm{~m}$ within rows (between hills). Plants were thinned to 2 plants per hill. Planting depth was approximately $3-5 \mathrm{~cm}$ and seeds covered with soil to enhance good germination and good seedling establishment. 
Table 1. Experiment layout for randomised complete bock design with four replicates

\begin{tabular}{|c|c|c|c|c|c|c|c|c|}
\hline Replication I & $\mathbf{V}_{1} \mathbf{T}_{3}$ & $\mathbf{V}_{1} \mathbf{T}_{2}$ & $\mathbf{V}_{1} \mathbf{T}_{1}$ & $\mathbf{V}_{2} \mathbf{T}_{4}$ & $\mathbf{V}_{1} \mathbf{T}_{4}$ & $\mathbf{V}_{2} \mathbf{T}_{3}$ & $\mathbf{V}_{2} \mathbf{T}_{1}$ & $\mathbf{V}_{2} \mathbf{T}_{2}$ \\
\hline Replication II & $\mathbf{V}_{2} \mathbf{T}_{3}$ & $\mathbf{V}_{1} \mathbf{T}_{1}$ & $\mathbf{V}_{\mathbf{1}} \mathbf{T}_{\mathbf{3}}$ & $\mathbf{V}_{2} \mathbf{T}_{1}$ & $\mathbf{V}_{1} \mathbf{T}_{2}$ & $\mathbf{V}_{2} \mathbf{T}_{4}$ & $\mathbf{V}_{1} \mathbf{T}_{4}$ & $\mathbf{V}_{1} \mathbf{T}_{2}$ \\
\hline Replication II & $\mathbf{V}_{2} \mathbf{T}_{4}$ & $\mathbf{V}_{2} \mathbf{T}_{1}$ & $\mathbf{V}_{1} \mathbf{T}_{2}$ & $\mathbf{V}_{1} \mathbf{T}_{1}$ & $\mathbf{V}_{1} \mathbf{T}_{3}$ & $\mathbf{V}_{2} \mathbf{T}_{3}$ & $\mathbf{V}_{1} \mathbf{T}_{3}$ & $\mathbf{V}_{2} \mathbf{T}_{3}$ \\
\hline Replication IV & $\mathbf{V}_{1} \mathbf{T}_{4}$ & $\mathbf{V}_{1} \mathbf{T}_{1}$ & $\mathbf{V}_{2} \mathbf{T}_{4}$ & $\mathbf{V}_{2} \mathbf{T}_{3}$ & $\mathbf{V}_{1} \mathbf{T}_{2}$ & $\mathbf{V}_{2} \mathbf{T}_{3}$ & $\mathbf{V}_{1} \mathbf{T}_{3}$ & $\mathbf{V}_{2} \mathbf{T}_{1}$ \\
\hline
\end{tabular}

Note: $\mathrm{V}_{1=}$ (SANIONI an improved local variety in Sotuba site, and SOSAT an improved variety from IER in Cinzana site) $\mathrm{V}_{2=}(\mathrm{CHO}$ a local variety in Sotuba and IBV8001 an improved variety from ICRISAT) $\mathrm{T}_{1=}$ Control, $\mathrm{T}_{2=}$ MANURE, $\mathrm{T}_{3=} \mathrm{NPK}, \mathrm{T}_{4}=\mathrm{NPK}+\mathrm{MANURE}$

\section{Data Collected}

Data were collected on all plants from the four central rows per plot in both locations. Data on seedling vigour were collected two weeks after planting and scored on a scale of 1 to 5 (1 $=$ excellent, $2=$ good, 3 = average, $4=$ poor, 5 = very poor). The plant stand was evaluated as the number of plants of millet in each plot after thinning. The recording of day of $50 \%$ heading was carried on the day at which $50 \%$ in experiment unit plants started to have panicle from boot. The flowering was recorded when $50 \%$ of an experimented unit had flowered.

The plant height was measured from the base of plant to tip of head at maturity. The data was taken on three plants per experimental unit and average three plants height were taken per plot. The number of harvested panicles was obtained by counting the number of productive panicles from the experimental plot. Panicle weight is the total of dry weight of the harvested panicle from the experimental plot. The numbers of hills harvested were collected by considering: numbers of harvested hills per plot that were taken; grain weight is the total grain weight of grain obtained after threshing the harvest panicles. Threshing and winnowing were done manually using sack and plastic bowls. After threshing and weighing, the seeds from the experimental unit, the weight of the 1000 grain was obtained and recorded. Grain yield was calculated using the following formula:

$$
\text { Grain yield }=\frac{\text { Grain weight per plot } x 10000}{\text { Area harvested }} \ldots \ldots \ldots \ldots \ldots \ldots \text { equation } 6.1
$$

Straw weight was recorded by weight of all plant harvested and dried from the harvest unit.

\section{Soil and crop management input.}

Soils in these zones are mainly sandy and loamy of low fertility and seasonally waterlogged or flooded clays. They are classified as Lixisol in the FAO classification. Soil-related modules were parameterized mainly with measured data from experiments carried out under 
optimal growth conditions, and from related literature. Disturbed and undisturbed soil samples which were taken in soil profiles $(0-10,10-20,20-40,40-120 \mathrm{~cm})$ prior to sowing, were analysed for organic carbon (OC \%), $\mathrm{pH}$ water, and particle size distribution as described in Hoogenboom et al. (1999). Input data related to soil characteristics include soil texture, number of layers in soil profile, soil layer depth, $\mathrm{pH}$ of soil for each depth, clay, silt and sand contents, organic matter, cation exchange capacity, etc. The soil profile data used in the parameterization of the model is presented in Table 2 and Table 3.

Table 2. Chemical properties at Cinzana site for model evaluation experiment

\begin{tabular}{lcccccccc}
\hline $\begin{array}{l}\text { Depth } \\
(\mathrm{cm})\end{array}$ & $\mathrm{pH}$ & $\mathrm{pH}$ & Sand \% & Silt \% & Clay \% & OM \% & $\mathrm{N} \%$ & $\begin{array}{c}\text { CEC } \\
\text { meq/100mg }\end{array}$ \\
\hline $0-10$ & 5.51 & 4.54 & 81.67 & 11.00 & 7.17 & 1.89 & 0.15 & 2.62 \\
$10-20$ & 5.44 & 4.37 & 76.67 & 9.67 & 13.00 & 1.76 & 0.14 & 3.43 \\
$20-40$ & 5.45 & 4.35 & 70.17 & 9.00 & 20.83 & 1.46 & 0.15 & 3.00 \\
$40-120$ & 5.45 & 4.35 & 70.17 & 9.00 & 20.83 & 1.46 & 0.15 & 3.00 \\
\hline
\end{tabular}

Table 3. Chemical properties at Sotuba site for model evaluation experiment

\begin{tabular}{|c|c|c|c|c|c|c|c|c|}
\hline $\begin{array}{l}\text { Depth } \\
(\mathrm{cm})\end{array}$ & $\begin{array}{l}\mathrm{pH} \\
(\mathrm{w})\end{array}$ & $\begin{array}{c}\mathrm{pH} \\
(\mathrm{KC})\end{array}$ & Sand $\%$ & Silt \% & Clay \% & $\begin{array}{c}\text { OM } \% \\
\mathrm{C}\end{array}$ & $\mathrm{N} \%$ & $\begin{array}{c}\text { CEC } \\
\text { meq/100mg }\end{array}$ \\
\hline $0-10$ & 5.77 & 4.83 & 72.06 & 21.28 & 6.59 & 1.32 & 0.88 & 5.47 \\
\hline $10-20$ & 5.70 & 4.63 & 70.13 & 19.25 & 10.69 & 1.24 & 0.85 & 5.10 \\
\hline $20-40$ & 5.75 & 4.61 & 66.59 & 19.19 & 14.13 & 1.14 & 0.73 & 5.44 \\
\hline $40-120$ & 5.75 & 4.61 & 66.59 & 19.19 & 14.13 & 1.14 & 0.73 & 5.44 \\
\hline
\end{tabular}

\section{Statistical Analyses}

The effect of the treatments and their interactions were analysed for the four following parameters: plants height, 1000 grain mass, grain yield and straw yield, with ANOVA performed with GENSAT V.9 Discovery Edition 4, Release 10.3DE (PC/Windows 7), Copyright 2011, VSN International Ltd. (Roth Amsted Experimental Station).

Using the General Treatment Structure (in Randomized Complete Blocks), ANOVA model included treatments, year and their interactions. Duncan Significant Difference (DSD) test was used for post-ANOVA multiple comparison $(\mathrm{P}<0.05)$ between means. Duncan significant tests were chosen because it can be used on raw data or in conjunction with an ANOVA test (Random complete block). 


\section{Macrothink}

\section{Results}

\section{Inter-Annual Rainfall Variability, Rainfall Distribution and its Relation with Crop Yields for Sotuba and Cinzana}

The rainfall distribution during the cropping season of 2013 and 2014 at Sotuba is illustrated in Figure $6.1 \mathrm{~A}$ and B. Overall, 60 to $75 \%$ of the total rain fell between June and September in Sotuba. In the same location in that year, 2013 was the wettest year with $713 \mathrm{~mm}$, compared to 2014 year with $640 \mathrm{~mm}$. The distribution of rainfall also varied from year to year and the analyses showed that in 2014 the rainfall was better distributed than in 2013. In 2013, it was observed that a 7 days' dry spell occurred in September, while in 2014 no day dry spell occurred even though the rainfall started in April with $0.4 \mathrm{~mm}$ of rainfall. In both years, the end of the rainy season did not show any dry spell period.

Figure $1 \mathrm{C}$ and $\mathrm{D}$ illustrate the rainfall distribution at Cinzana during the cropping season in 2013 and 2014. Though, 60 to $85 \%$ of the total rain occurred between July and September in Cinzana. Contrary to Sotuba, the year 2014 at Cinzana was wetter with $443 \mathrm{~mm}$ compared to the rainfall of $382 \mathrm{~mm}$ recorded in 2013. Two dry spells periods occurred in 2013 with 9 and 18 days' dry spell period in July and October respectively. In 2014 two dry spell periods was also observed with 9 and 11 days' dry spell periods in August and September. In both years, the rain started in April with rainfall of 0.4 and $6.6 \mathrm{~mm}$ for 2014 and 2013 respectively. The end of the rainy season was dry in 2013, with only $0.63 \mathrm{~mm}$ of rain in October against 0.91 $\mathrm{mm}$ in 2014. 

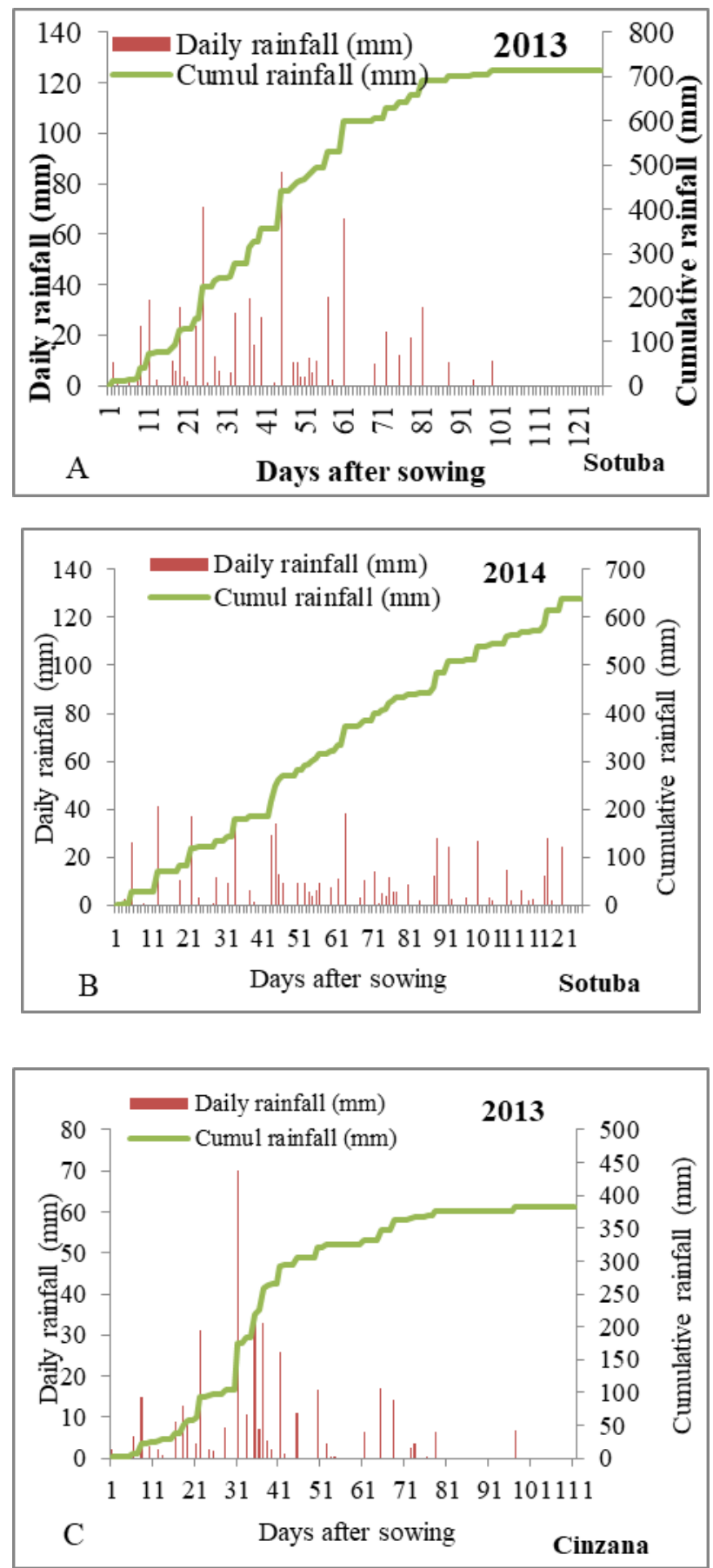


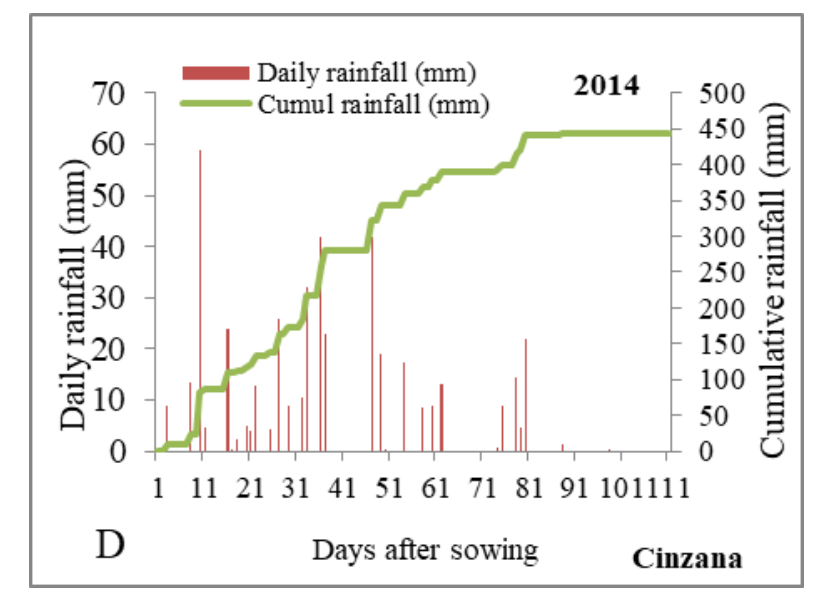

Figure 1. Rainfall distribution in 2013 and 2014 in Sotuba (A and B) and in Cinzana (C and D)

\section{Effect of inorganic and organic fertilizer on pearl millet growth and yields}

\section{Plant Height}

At Sotuba, the average plant height was $2.9 \mathrm{~m}$ and $3.6 \mathrm{~m}$ for 2013 and 2014 respectively (Figure 2) and CV of $10.9 \%$. The analyses showed high significant differences $(<0.001)$ between the years for plant height (Table 4). It also showed a high significant difference $(<0.001)$ between years and varieties interaction (Table 4). The plant height of CHO and Sanioni varieties varied according to year. At Cinzana, the average plant height observed was $2.3 \mathrm{~m}$ in 2013 and $3.6 \mathrm{~m}$ in 2014 and a CV of $11.7 \%$ (Table 5). The analyses showed high significant differences $(<0.001)$ between year 2013 and 2014 and did not show any statistical differences for any interactions. 
Table 4. Summary of analysis of variance on Yields and Yield components of two (2) varieties evaluated in Sotuba in the Sudanian agro-ecological zone

\begin{tabular}{|c|c|c|c|c|c|}
\hline \multirow[b]{2}{*}{ Source of variance } & \multirow[b]{2}{*}{$\mathrm{df}$} & \multicolumn{4}{|c|}{ F pr. } \\
\hline & & $\begin{array}{l}\text { Grain Yield } \\
\mathrm{kg} \mathrm{ha}^{-1}\end{array}$ & $\begin{array}{c}\text { Straw Yield } \\
\mathrm{kg} \mathrm{ha}^{-1}\end{array}$ & $\begin{array}{c}1000 \text { grain weight } \\
\text { (g) }\end{array}$ & $\begin{array}{c}\text { Plant } \\
\text { height }(\mathrm{m})\end{array}$ \\
\hline Years $(\mathrm{Y})$ & 1 & 0.002 & $<.001$ & 0.001 & $<.001$ \\
\hline Varieties (V) & 1 & 0.683 & $<.001$ & $<.001$ & 0.094 \\
\hline Fertilizers (F) & 3 & $<.001$ & $<.001$ & 0.223 & 0.256 \\
\hline$Y \times V$ & 1 & 0.349 & 0.003 & $<.001$ & $<.001$ \\
\hline$Y \times F$ & 3 & $<.001$ & 0.261 & 0.397 & 0.449 \\
\hline$V \times F$ & 3 & 0.631 & 0.816 & 0.245 & 0.944 \\
\hline$Y \times V \times F$ & 3 & 0.698 & 0.866 & 0.887 & 0.857 \\
\hline Residual & 45 & & & & \\
\hline Total & 63 & & & & \\
\hline $\mathrm{CV} \%$ & & 18.1 & 20.0 & 8.4 & 10.9 \\
\hline
\end{tabular}

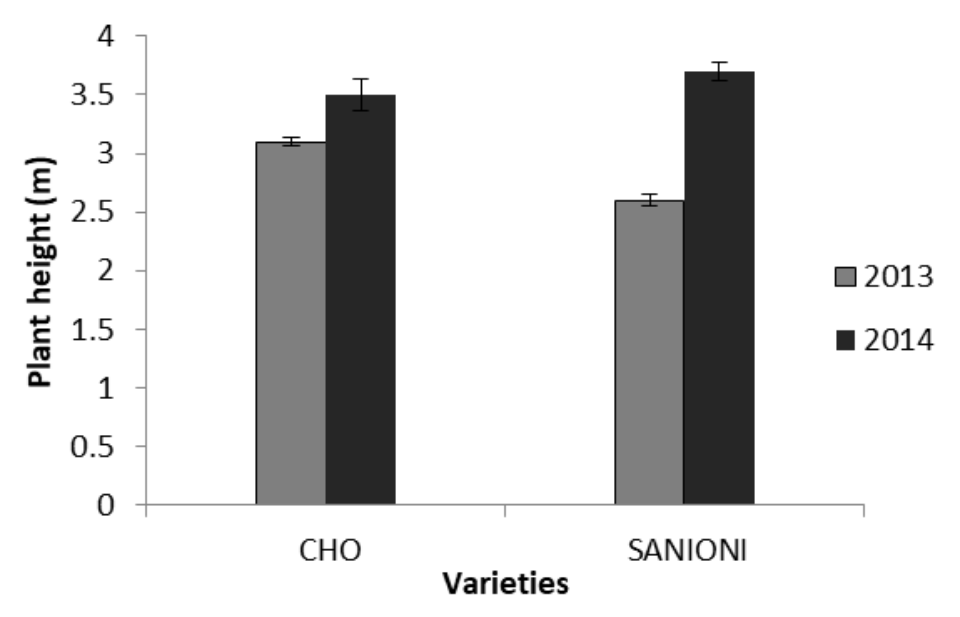

Figure 2 Varieties for plant height yields in 2013 and 2014

\section{Grain Weight}

At Sotuba, the average 1000 grain weight was $9.6 \mathrm{~g}$ and $8.7 \mathrm{~g}$ for $\mathrm{CHO}$ and SANIONI respectively. The analyses revealed significant differences between the two years $(0.001)$ (Table 6.4). Highly significant differences were observed between varieties $(<0.001)$ and the interaction between years and varieties $(<0.001)$ was significant. In 2013 , the variety CHO 


\section{Macrothink}

showed higher 1000 grain weight with $10.17 \mathrm{~g}$ compared to variety SANIONI (7.53 g) while in 2014 the variety SANIONI had higher 1000 grain weight (9.94 g) compared to variety CHO with (9.12 g). The 1000 grain weight gap between the year 2013 and 2014 for variety SANIONI was higher than that of the variety $\mathrm{CHO}$ for the same years (Figure 3). On the contrary, at Cinzana, the analysis did not show any statistically significant differences for the variable 1000 grain weight.

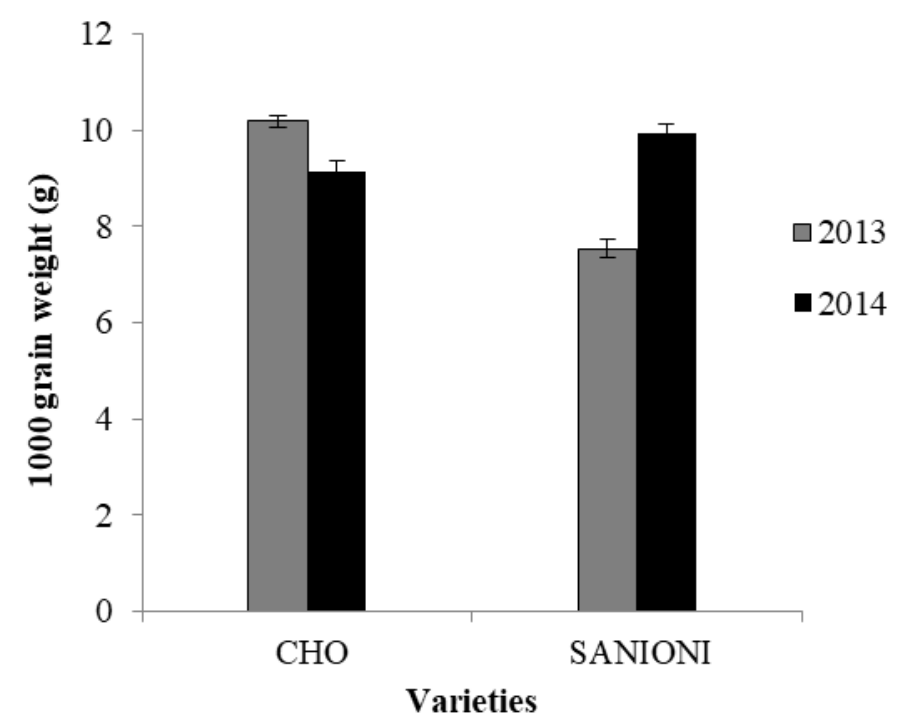

Figure 3 Varieties 1000 grain weight in 2013 and 2014 in Sotuba

Table 5. Summary of analysis of variance on Yields and Yield components of two (2) varieties evaluated in Cinzana a Sahelian agro-ecological zone

\begin{tabular}{lccccc}
\hline \multicolumn{5}{c}{ F pr. } \\
\hline Source of variation & Df & $\begin{array}{c}\text { Grain Yield kg } \\
\text { ha }^{-1}\end{array}$ & $\begin{array}{c}\text { Straw Yield kg } \\
\text { ha }^{-1}\end{array}$ & $\begin{array}{c}1000 \text { grain } \\
\text { weight }(\mathrm{g})\end{array}$ & $\begin{array}{c}\text { Plant height } \\
\text { (m) }\end{array}$ \\
Years (Y) & 1 & 0.094 & $\mathbf{0 . 0 4}$ & 0.925 & $<.001$ \\
Varieties (V) & 1 & 0.779 & 0.129 & 0.328 & 0.244 \\
Fertilizers (F) & 3 & 0.055 & 0.058 & 0.8 & 0.33 \\
Y x V & 1 & $\mathbf{0 . 0 2}$ & 0.452 & 0.791 & 0.236 \\
Y x F & 3 & $\mathbf{0 . 0 0 2}$ & 0.387 & 0.984 & 0.448 \\
V x F & 3 & 0.711 & 0.399 & 0.742 & 0.985 \\
Y x V x F & 3 & 0.2 & 0.331 & 0.691 & 0.821 \\
Residual & 45 & & & & \\
Total & 63 & & 30.9 & 16.7 & 11.7 \\
CV\% & & 22.4 & &
\end{tabular}




\section{Macrothink}

\section{Straw Weight}

At Sotuba, the average straw yield was $9714 \mathrm{~kg} \mathrm{ha}^{-1}$ and $31487 \mathrm{~kg} \mathrm{ha}^{-1}$ for year 2013 and 2014 respectively. The analyses revealed high significant differences between years $(<0.001)$, between varieties $(<0.001)$ and among fertilizer treatments $(<0.001)$. Table 6.4 showed significant differences between years and varieties interaction (0.003) with a CV of $20 \%$. Figure 6.4 showed an interaction between years and varieties. The total straw produced in 2014 (34999 $\mathrm{kg} \mathrm{ha}^{-1}$ ) by the variety SANIONI was 3 times higher than produced in 2013 $\left(1000 \mathrm{~kg} \mathrm{ha}^{-1}\right)$ by the same variety. In 2014, the local variety CHO produced higher straw production with $27975 \mathrm{~kg} \mathrm{ha}^{-1}$. In 2014, the quantity of straw produced by SANIONI was higher than that produced by $\mathrm{CHO}$ while in 2013 both varieties had similar amounts of straw produced.

At Cinzana, the average straw quantity produced was $9270 \mathrm{~kg} \mathrm{ha}^{-1}$ in 2013 and $7867 \mathrm{~kg} \mathrm{ha}^{1}$ in 2014 and a CV of $30.9 \%$ (Table 5). The analyses showed significant differences (0.04) between year 2013 and 2014 and did not show any statistical difference for the other factors and their interactions.

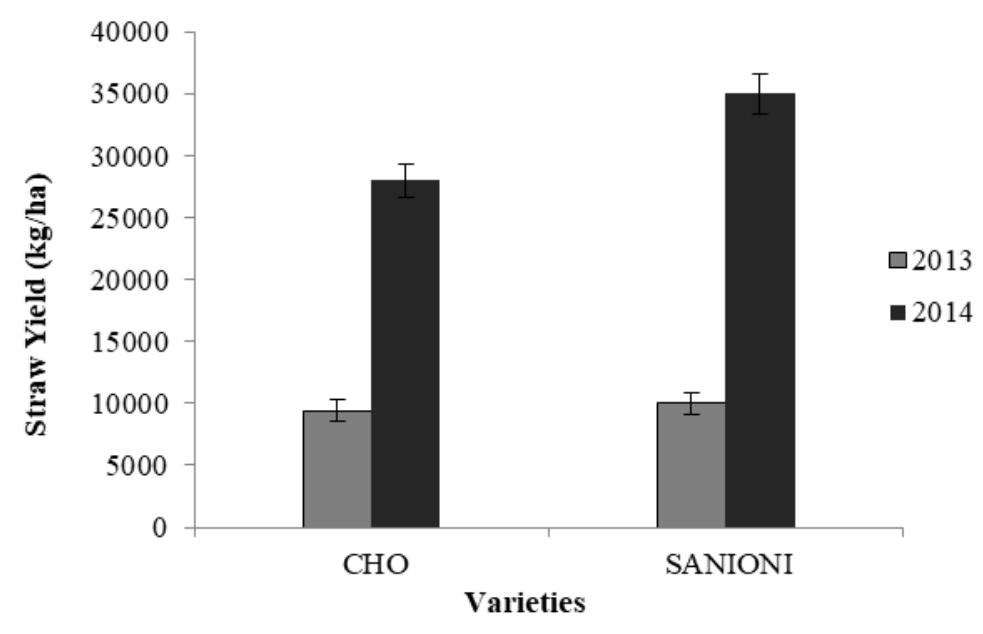

Figure 4 Straw yields in 2013 and 2014 in Sotuba

\section{Grain Yield}

At Sotuba, the average grain yield was $1293 \mathrm{~kg} \mathrm{ha}^{-1}$ and $1503 \mathrm{~kg} \mathrm{ha}^{-1}$ for year 2013 and 2014 respectively. The analyses revealed significant differences between years $(0.002)$. Table 4 showed high significant differences among fertilizer treatments $(<0.001)$ and between years and fertilizer interaction $(<0.001)$ with a CV of $18.1 \%$. In 2013 , the analyses revealed high grain yield in the combined organic manure and NPK (NPK+MANURE) treatment with 1948 $\mathrm{kg} \mathrm{ha}^{-1}$, followed by NPK (1281 kg ha $\left.{ }^{-1}\right)$, MANURE (1130 kg ha' $)$ and Control $\left(813 \mathrm{~kg} \mathrm{ha}^{-1}\right)$. In 2014, the grain yield with fertilizer treatment (NPK+MANURE) was $1602 \mathrm{~kg} \mathrm{ha}^{-1}$, followed by NPK with grain yield (1502 $\left.\mathrm{kg} \mathrm{ha}^{-1}\right)$, MANURE was (1466 kg ha') and control was $\left(1440 \mathrm{~kg} \mathrm{ha}^{-1}\right.$ ) (Figure 5). The grain yield gap for the Control treatment in 2013 (813 kg $\mathrm{ha}^{-1}$ ) and in 2014 (1440 $\mathrm{kg} \mathrm{ha}^{1}$ ) was high compared to the NPK+MANURE, MANURE and NPK treatment grain yield gap for the same years. 


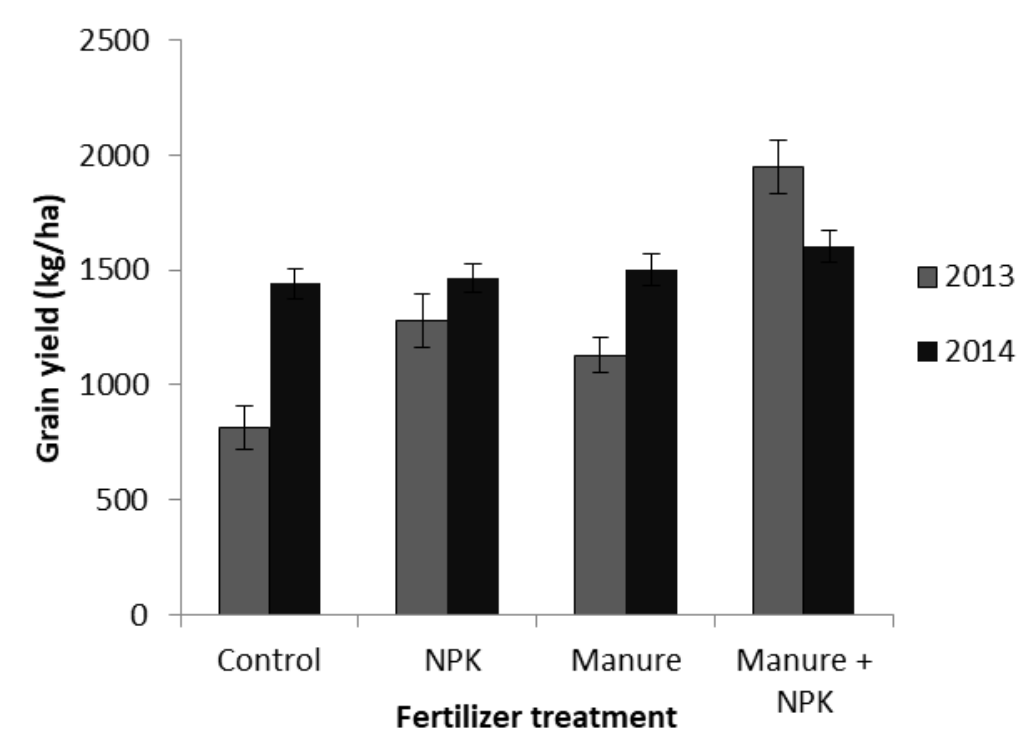

Figure 5 Fertilizer and years for grain yields in 2013 and 2014 in Sotuba

At Cinzana, the average grain yield observed in 2013 and 2014 was 1390 and $1530 \mathrm{~kg} \mathrm{ha}^{-1}$ respectively. The analyses did not show any significant differences between the varieties and among the fertilizer treatments. However, significant differences were found in the following interactions: years $\mathrm{x}$ varieties (0.02) and years x fertilizer treatments $(0.002)$ with a $\mathrm{CV}$ of $22.4 \%$ (Table 6.5). In 2013, variety SOSAT showed higher grain yield (1447 kg ha-1) than IBV8001 (1333 $\mathrm{kg} \mathrm{ha}^{-1}{ }^{1}$ ) while in 2014, variety IBV8001 showed higher grain yield (1614 $\mathrm{kg} \mathrm{ha}^{-1}$ ) than SOSAT (1545 kg ha ${ }^{-1}$. Figure 6.6a showed an interaction between years and varieties; thus, the grain yield gap of the variety IBV8001 in $2013\left(1333 \mathrm{~kg} \mathrm{ha}^{-1}\right)$ and in 2014 $\left(1614 \mathrm{~kg} \mathrm{ha}^{-1}\right)$ was higher compared to SOSAT in year $2013\left(1447 \mathrm{~kg} \mathrm{ha}^{-1}\right)$ and in 2014 (1545 $\left.\mathrm{kg} \mathrm{ha}^{-1}\right)$. In 2013, the analyses revealed higher grain yield with the treatments of NPK+MANURE, $\left(1440 \mathrm{~kg} \mathrm{ha}^{-1}\right)$, NPK (1429 kg ha ${ }^{-1}$ ), MANURE (1416 kg ha') compared to Control (1276 kg ha ${ }^{-1}$ ). In 2014, the Figure 6.6b showed the highest grain yield with NPK+MANURE (1915 kg ha $\left.{ }^{-1}\right)$ followed by NPK (1561 kg ha' $\left.{ }^{-1}\right)$, MANURE (1523 kg ha ${ }^{-1} 1$ ) and Control $\left(1121 \mathrm{~kg} \mathrm{ha}^{-1}\right)$. The grain yield gap for the combined NPK+MANURE treatment in 2103 (1440 kg ha 1$)$ and in 2014 (1915 $\left.\mathrm{kg} \mathrm{ha}^{1}\right)$ was high compared to the others for the fertilizer grain yield gap for both years. 

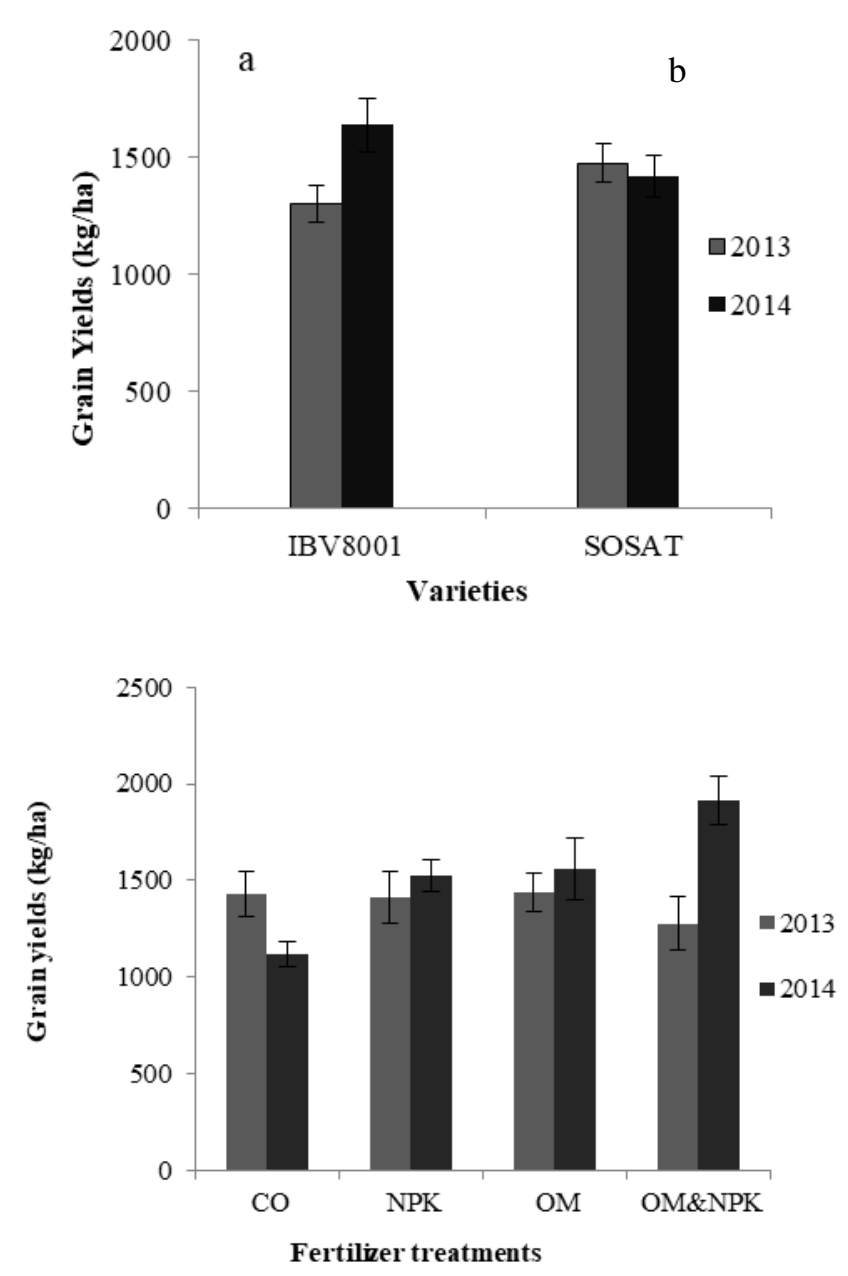

Figure 6a and b. Year x varieties and year x amendments for grain yields in 2013 and 2014 in Cinzana

\section{Discussion}

The rainfalls in both years at Sotuba were higher than that for Cinzana. This is expected because Sotuba is located in Sudanian zone while Cinzana is in the Sahelian zone. In 2013, dry spell periods were observed in both locations. Sotuba experienced only one dry spell period in year 2013 while it appeared twice in both years at Cinzana. The dry spell period at Sotuba that occurred in September corresponded to the flowering period of the crops. In 2013 at Cinzana the dry spell periods occurred in July corresponding to planting period of the crop while the one in October corresponded to the plant maturity period. The dry spell periods occurred in 2014 at Cinzana in August and September are the periods of the crop flowering and grain filling. Study done by Le Barbé et al., (2002), on rainfall variability in West Africa during the years 1950-90 showed similar results, where they defined that the ration between the number of rain events and the number of rainy days will depend on the location and period of year considered. In the Southern part of the West African Sahel the rainfall season starts earlier and end later than in the north (Traoré et al., 2000; Traoré et al., 2007).

The analysis of rainfall revealed sequences of dry spells which may affect crop yields. The 
highest in dry spell of 5 to 10 occurred in May and October (result not shown in the report). This showed the irregularity of rainfall in May which represents the land preparation in Sudanian-Sahelian zones of Mali, and which may delay the planting date and reduce the rainy season length for cropping period. Many farmers agreed that the rainy season which start early are mostly better for crop production than late rainy season (Sivakumar and Hatfield, 1990; Stewart, 1991). This is confirmed by the finding in 2014 at Sotuba by the researcher where the rainy season started early without any dry spell period in the cropping season resulting in higher yield. The date of started of rainy season was demonstrated to be the key variable to all other seasonal rainfall (Traoré et al., 2014).

The rainfall at Sotuba in 2013 (713) and 2014 (640) were lower for the average rainfall of that location which was between 800 and $1100 \mathrm{~mm}$. The same trend was observed at Cinzana with rainfall in $2013(382 \mathrm{~mm})$ and $2014(443 \mathrm{~mm})$ compared to the average rainfall between 650 and $800 \mathrm{~mm}$. Rainfall is process by nature; therefore, lack of reliable rainfall to allow a positive response of a crop to soil fertility management strategies for the crop productivity is increasing in West Africa Sahel (Bationo et al., 1990; Rezaei et al.; 2014). At Sotuba the highest grain yield was obtained with NPK+MANURE treatment. The differences among the grain yields of the different fertilizer treatments compared to the Control were higher in 2013 showing the advantage of using fertilizer in the cropping system. At Cinzana, beside the low rainfall, the varieties showed differences according to the years and the fertilizer treatments. The differences among the grain yields of the different fertilizer treatments compared to the Control were higher in 2014 showing the advantage of using fertilizer in the cropping system. Furthermore, pearl millet is adapted to dry conditions and is sensitive to water stress particularly when this occurs during the flowering stage as was the case in the present study in 2013 and 2014 for the Cinzana location.

Millet is one of the most important foods in the Sahelian and the Sudano-Sahelian zones of Mali. The lower growth and yield parameters recorded in varieties could be attributed to uneven rainfall distribution, which cause water availability problems that affect soil aeration, amendment use efficiency and plant metabolism such as photosynthesis thus inducing good plant growth and development. Therefore, in this study, pearl millet responded positively to different fertiliser treatments imposed and manure application improved millet yield production significantly as compared to the no fertilizer (Control) application for both sites. There was a significant increase of grain yield production when manure was added to NPK.

\section{Conclusion}

The low productivity of millet crop in the Sahelian and Sudanian zones is caused by poor soil fertility due to uncertain rainfall conditions. The results of the present study showed that millet production could be improved further by combining inorganic fertilizers with the application of manure. The highest grain yield was obtained with Organic matter + NPK combined application and the control as expected obtained the lowest yield.

Millet grain yield in both ago ecological zones can be improved by using both organic and inorganic sources of fertilizer. 


\section{References}

Bationo, A., \& Buerkert, A. (2001). Soil Organic Carbon Management for Sustainable Land Use in Sudano-Sahelian West Africa. Nutrient Cycling in Agroecosystems, 61(1-2), 131-142.

Bationo, A., Christianson, C. B., \& Baethgen, W. E. (1990). Plant Density and Nitrogen Fertilizer Effects on Pearl Millet Production in Niger. Agronomy Journal, 82, 290-295.

Breman, H., \& Sissoko, K. (1998). L'intensification Agricole au Sahel. Paris, Karthala Editions, 996.

Chakraborty, S., \& Newton, A. C. (2011)Climate change, plant diseases and food security: an overview. Plant Pathol., 60, 2-14.

De Graaff, J., Kessler, A., \& Nibbering, J.W. (2011). Agriculture and food security in selected countries in Sub-Saharan Africa: diversity in trends and opportunities. Food Security, 3(2), 195-213.

Doumbia, M, Jarju, A., Sene, M., Traore, K., Yost, R., Kablan, R, et al. Sequestration of organic carbon in West African soils by Aménagement en Courbes de Niveau. Agron Sust Dev. 2008

Drechsel, P., Gyiele, L., Kunze, D., \& Cofie, O. (2001). Population Density, Soil Nutrient Depletion, and Economic Growth in Sub-Saharan Africa. Ecological Economics, 38(2), 251-258.

Ehui, S., \& Pender, J. (2005). Resource Degradation, Low Agricultural Productivity, and Poverty in Sub-Saharan Africa: Pathways out of the Spiral. Agricultural Economics, 32(1), 225-242.

FAO. (2012). Twenty-Seventh FAO Regional Conference for Africa. ARC/12/REP Rev.1, Brazzaville Congo 23-27 April 2012.

Giller, K. E., Tittonell, P., Rufino, M. C., Van Wijk, M. T., Zingore, S., Mapfumo, P., ... \& Vanlauwe, B. (2011). Communicating Complexity: Integrated Assessment of Trade-Offs Concerning Soil Fertility Management Within African Farming Systems to Support Innovation and Development. Agricultural Systems, 104(2), 191-203.

Le Barbé, L., Lebel, T., \& Tapsoba, D. (2002). Rainfall Variability in West Africa During the Years 1950-90. Journal of Climate, 15(2), 187-202.

Oushy, H. (2010). Pearl millet fact sheet. NMSU-AWATT, Afghanstan. Poelhman, J. M. 1994. Breeding field crops. 3rd Edn. AVI Pub, Connecticut

Rai, K. N., Govindaraji, M., \& Rao, A. S. (2012). Genetic enhancement of grain iron and zinc content in pearl millet. Quality assurance and safety of crops and foods, 4(3), 1119-1125.

Rezaei, E. E., Gaiser, T., Siebert, S., Sultan, B., \& Ewert, F. (2014). Combined impacts of climate and nutrient fertilization on yields of pearl millet in Niger. European Journal of Agronomy, 55, 77-88. 


\section{Macrothink

Sivakumar, M., \& Hatfield, J. (1990). Spatial variability of rainfall at an experimental station in Niger, West Africa. Theoretical and applied climatology, 42(1), 33-39.

Stewart, J. I. (1991). Principles and performance of response farming. In: R.C. Muchow and J.A. Bellamy (Editors), Proceedings of the international symposium on Climatic risk in crop production: Models and management for the semiarid tropics and subtropics, Brisbane, Australia, 361-382.

Traore, B, Vanwijk, M. T., Descheemaeker, K., Corbeels, M., Rufino, M. C., \& Giller, K. E. (2014). Farmer's Perceptions On Climate Change and On Agricultural Adaptation Strategies in Southern Mali. Experimental Agriculture, 51(4), 615-634.

Traoré, P. C. S., Kouressy, M., Vaksmann, M., Tabo, R., Maikano, I., Traoré, S. B., \& Cooper, P. (2007). Climate Prediction and Agriculture: What Is Different About Sudano-Sahelian West Africa? Chapter 19. In: M.V.K. Sivakumar and J. Hansen (Editors), Climate Prediction and Agriculture: Advances and Challenges. Springer, USA, 189-203.

Traoré, S. B., Reyniers, F. N., Vaksmaann, M., Koné, B., Sidibé, A., Yoroté, A., \& Yattara, K. (2000). Adaptation a la Sécheresse des Ecotypes Locaux de Sécheresse. Sécheresse, 11, 227-237.

Vanlauwe, B., Bationo, A., Chianu, J., Giller, K. E., Merckx, R., Mokwunye, U., O... \& Sanginga, N. (2010). Integrated Soil Fertility Management. ISSN 0030-7270, 17-24.

Wilson, J. P. (2011). Breeding pearl millet with improved performance, stability, \& resistance to pests. International Sorghum Millet and Other Grains Collaborative Research Support Programme, 113 Biochemistry Hall, Lincoln.

Yadav, O. P. (2010). Drought response of pearl millet landraces and their crosses with elite composites. Field Crops Research, 118, 51-56.

\section{Copyright Disclaimer}

Copyright for this article is retained by the author(s), with first publication rights granted to the journal.

This is an open-access article distributed under the terms and conditions of the Creative Commons Attribution license (http://creativecommons.org/licenses/by/4.0/) 